\title{
Optimization of Milk Performance and Quality in Dairy Farms by using a Quarter individual Milking System "MultiLactor"
}

\author{
Kaskous S.
}

Department of Research and Development, Siliconform, Schelmengriesstraße 1, D-86842 Türkheim, Germany

skaskous@siliconform.com

\begin{abstract}
Within the daily work on dairy farms milk harvesting is a crucial factor in optimizing milk performance and quality. The objective of this study was to investigate the influence of optimizing the milking process by using a quarter individual milking system "MultiLactor" (ML) on milk performance and quality. 170 Holstein-Friesian dairy cows were used on a farm in Switzerland. The cows were milked three times a day with an ML milking system. Recording of milk yield and collecting of milk sample were carried out monthly from each cow for one year. After that, the main milk parameters were analyzed by Association of Milk Records Switzerland. The primary milk data was processed with Excel program. Thereafter, analysis was carried out using the Statistical Analysis System (SAS). The average milk yield was 35.84 \pm 0.28 $\mathrm{kg} / \mathrm{cow} /$ day. This corresponds to an annual milk yield of $12000 \mathrm{~kg} / \mathrm{cow}$. The mean values of milk composition were $4.36 \pm 0.02 \%, 3.28 \pm 0.01 \%, 4.75 \pm 0.01 \%, 20.65 \pm 0.20 \mathrm{mg} / \mathrm{dl}$ and $99.63 \pm 6.48 \times 10^{3} \mathrm{cells} / \mathrm{ml}$ for fat, protein, lactose, urea and somatic cell count (SCC) respectively. It was also shown that the cows remained healthy in the farm during the study period. In conclusion, the obtained results demonstrated that the cows produced a higher milk yield with good quality, since the milking system adapts the physiological requirements of dairy cows.
\end{abstract}

Keywords---Cow, Fat, Lactose, Milk, MultiLactor, Protein, Somatic Cell Count, Urea.

\section{INTRODUCTION}

Every day, billions of people around the world consume milk and milk products, which play a key role in healthy human nutrition and development throughout life. Currently, dairy cows are the main source of milk production in the world. Milking is a central part in dairy management in order to optimize milk production and quality. Mechanical milk removal is indispensable in today's milk production. In this process, you have to consider that the milking machine is the technology that works directly on the animal (1). The main requirement for every milking system is to achieve the greatest possible milk yield in the shortest possible time, with the least amount of work and without harming the udders of the cows (2). Thus, the key to successful milk removal lies in the optimal realization of all these factors (3). At this point, research and development relating to milking machine plays a crucial role. The interaction between animals, humans and milking technology, in terms of animal welfare and milk letdown and the optimization of the milking workplace are becoming increasingly important $(4,5)$. In addition to many other factors, milking technology has a significant impact on milk performance, improved milk ingredients and lower cell counts (6-9). Nowadays, different milking technologies can be used for the milking process in the world. But milking equipment and routine need to be adjusted according to the animals' physiology mechanism in order to achieve optimal milk removal $(10,11)$.

For these reasons, ML milking system was developed by Silicon form in Germany and used in the field since 2008. The field results have shown that the using of ML in comparison with the conventional milking systems is more effective in term of positive stimulation effect (12). Furthermore, it was shown that ML milking system had a positive influence on milk yield and composition (10). These results confirm the importance of the type of used milking machine in dairy farms. 
The aim of this study was therefore to investigate the influence of the optimization of the milking process by using a quarter individual milking system ML on the milk yield and its composition.

\section{MATERIAL AND METHODS}

\subsection{Research location:}

The present study was conducted in the department of research and development of Silicon form in Germany and in a dairy farm in Switzerland, which has organized everything almost perfectly from rearing calves to old cows.

\subsection{Animals and husbandry:}

170 Holstein-Friesian dairy cows were used (Fig. 1). The cows were kept in loose housing and they were fed ad libitum with a partial mixed ration (grass-and corn-silage, hay) and received concentrate according to the production level. Furthermore, the cows received fresh feed three times a day and each animal had a feeding place. The farm is also one of the first to use sandboxes for lying the cows, which was $1.30 \mathrm{~m}$ wide and $2.90 \mathrm{~m}$ long. In the dry period, the cows were placed on a deep straw mat with specific feed ration. Research has clearly demonstrated the impact of dry period nutrition and management on postpartum health and performance. The goal for dry cows in the farm include: maintain dry matter intake, optimize comfort, prevent body condition score gain, and address hoof health. After calving, feed intake for lactating cows was optimized and the fresh calves were taken into good place, which was very comfortable.

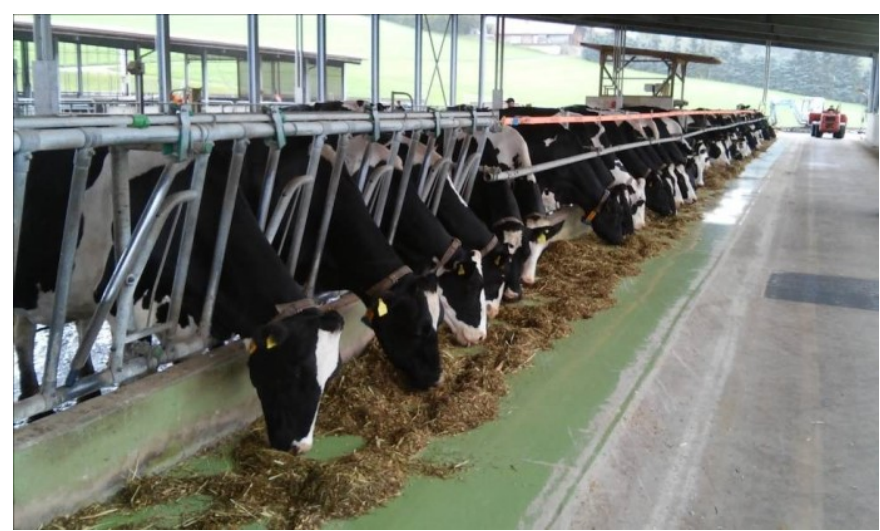

Fig.1: Herd of the examined field farm.

\subsection{Used milking system:}

All dairy cows were milked three times a day at 5:00, 13:00 and 21:00 hours in a carousel milking parlor (24 places) with a ML milking system (Fig. 2).

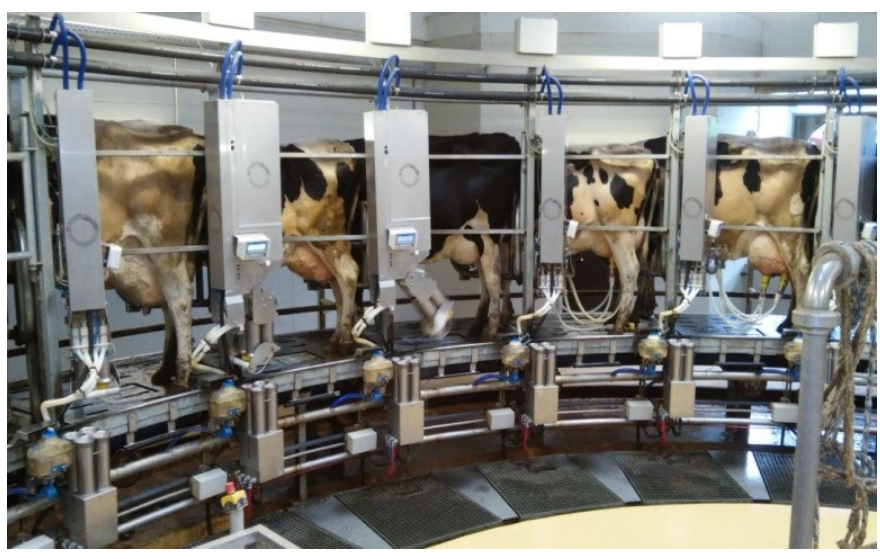

Fig. 2: The new milking technology ML in the carousel milking parlor.

\subsection{Characteristics milking system:}

ML is the essential instrument of an innovative milking process, which has set new standards in milking technology. ML is a well-handled and animal-friendly semi-automatic milking system that differs technically from conventional milking machine. It is based on a quarter-individual milking system. Features and characteristics of the used milking technology are summarized in Table 1:

Table 1. Features of the used milking technology.

\begin{tabular}{|l|l|}
\hline Parameters & Feature \\
\hline Milking vacuum $(\mathrm{kPa})$ & 34 \\
\hline Pulse rate (cycles/min) & 60 \\
\hline Pulsation ratio & $60: 40$ \\
\hline Pulsation type & sequential \\
\hline Air intake & Periodically in the teat cup \\
\hline Teat cup removal & Fully automatically \\
\hline $\begin{array}{l}\text { Cleaning and } \\
\text { intermediate disinfection }\end{array}$ & $\begin{array}{l}\text { After each milked cow } \\
\text { and after the milked herd }\end{array}$ \\
\hline Dipping & Automatic dipping \\
\hline
\end{tabular}

\subsection{Milk routine:}

At the milking time in the investigated farm, the cows came voluntary to the milking parlor. After identification of the cow the ML automatically turns into attachment position directly in front of the udder. Afterwards, the milker has cleaned the teats, pre-milked and visually checked the milk. Then, each teat cup is individually or in pairs pulled out of the magazine and manually attached to 
the teats. Subsequent to this step, the system is started on the control display and the pre-stimulation begins. The prestimulation is structured to be intensively activated with a normal pulse rate (60 cycles/min) and reduces the milking phase (b-phase) of $10 \%$ over a period of $50 \mathrm{~s}$. At the same time, intensive movement of the teat cups is regulated as an additional stimulation by an actuator. This is an arm on which the four milk tubes are placed. During the prestimulation and the milking time, this arm moves up and down. This movement is transferred to the teat cups and makes the teats erect.

After stimulation the main milk phase begins and the milk flow is observed on the display. When the milk flow has decreased to a certain level, the milking process is automatically stopped by detaching the milking unit and each teat is dipped with a solution containing Chlorexidin. After milking, the teat cups are cleaned and disinfected automatically with water and per acetic acid solution $(0.5 \%)$.

\subsection{Milk recording, sampling and analysis:}

Recording of milk yield and collecting of milk sample were carried out monthly from each cow of the experimental farm during the study period. The milk samples have been analyzed for fat, protein, lactose, urea and SCC by Association of Milk Records Switzerland. Electronic fluorescence was used to analyse SCC in the milk samples. The mid-infrared spectroscopy method was used for the determination of gross milk composition (fat, protein, lactose \%). Infrared measurement with PLS calibration was used to determine the urea in the milk.

\subsection{Statistical Analysis:}

All milk parameters measured were analysed by ANOVA, using the SAS Statistical Software Package (SAS Institute, Cary, NC, 1998) (13) and the Least Square Means (LSM) were compared using F-Test. The results were shown as $\mathrm{LSM} \pm \mathrm{SE}$.

\section{THE RESULTS}

\subsection{General mean values of the examined parameters:}

The average daily milk yield for the entire investigation period was $35.84 \pm 0.28 \mathrm{~kg} / \mathrm{cow}$ (Tab.2). This corresponds to an annual milk production of 12000 $\mathrm{kg} / \mathrm{cow}$. Despite the higher milk yield, the composition of the extracted milk remained high and the mean values were $4.36 \pm 0.02 \%, 3.28 \pm 0.01 \%$ and $4.75 \pm 0.01 \%$ for fat, protein and lactose respectively. The milk urea content was within the normal range $(20.65 \pm 0.20 \mathrm{mg} / \mathrm{dl})$ during the study period. This urea level in milk was lead back to the perfect balance between energy and protein in the ration.

It is noteworthy that with high daily milk yield per cow, low SCC have been achieved and the average values remained below $100 \times 10^{3}$ cells $/ \mathrm{ml}$ milk during the study period. The statistical results showed that the average lactation number was at 3.31 in the examined farm.

Table 2. The average ( $L S M \pm S E)$ milk parameters of the examined farm:

\begin{tabular}{|l|l|l|l|}
\hline Parameters & LSM \pm SE & $\begin{array}{l}\text { Minimal } \\
\text { value }\end{array}$ & $\begin{array}{l}\text { Maximal } \\
\text { value }\end{array}$ \\
\hline $\begin{array}{l}\text { Milk yield } \\
\mathrm{kg} / \text { day }\end{array}$ & $35.84 \pm 0.28$ & 7.10 & 68.60 \\
\hline Fat \% & $4.36 \pm 0.02$ & 2.27 & 7.74 \\
\hline Protein \% & $3.28 \pm 0.01$ & 2.11 & 5.02 \\
\hline Lactose \% & $4.75 \pm 0.01$ & 3.59 & 5.25 \\
\hline Urea mg/dl & $20.65 \pm 0.20$ & 5.00 & 46.00 \\
\hline $\begin{array}{l}\text { SCC x } 10^{3} \\
\text { cells/ml }\end{array}$ & $99.63 \pm 6.48$ & 6000 & 300000 \\
\hline $\begin{array}{l}\text { Lactation } \\
\text { number }\end{array}$ & $3.31 \pm 0.04$ & 1.00 & 8.00 \\
\hline
\end{tabular}

\subsection{Influence of the stage of lactation on the examined milk parameters:}

Table (3) showed that the daily milk yield remained relatively high until the end of lactation and the values were $41.62 \pm 0.39,36.97 \pm 0.39$ and $29.66 \pm 0.39 \mathrm{~kg} /$ day in the first, second and third stage of lactation respectively. Furthermore, the persistence of daily milk production were $88.83 \%$ and $71.26 \%$ in the second and third stage of lactation.

The change in milk composition with the progress of lactation session have shown a clear ideal tendency. Fat $(4.23,4.28$ and $4.56 \%, \mathrm{P}<0.05)$ and protein $(3.01,3.29$ and $3.51 \%, \mathrm{P}<0.05)$ content in the milk increased and lactose (4.80, 4.76 and $4.68 \%, \mathrm{P}<0.05)$ content decreased in the first, second and third stage of lactation respectively.

The SCC of milk remained low in the first stage of lactation $\left(82.49 \pm 10.42 \times 10^{3}\right.$ cells $\left./ \mathrm{ml}\right)$ and then it increased slightly with no significant differences $(\mathrm{P}>0.05)$ and the values were $107.55 \pm 10.42 \times 10^{3}$ and $108.86 \pm 6.98 \times 10^{3}$ in the second and third stage of lactation respectively. 
Table 3. Average (LSM $\pm S E)$ milk parameters of the examined farm according to the stage of lactation.

\begin{tabular}{|l|l|l|l|}
\hline \multirow{2}{*}{$\begin{array}{l}\text { Milk } \\
\text { parameter }\end{array}$} & \multicolumn{3}{|c|}{ Stage of lactation } \\
\cline { 2 - 4 } & $<100$ days & $100-200$ days & $>200$ days \\
\hline $\begin{array}{l}\text { Milk yield } \\
(\mathrm{kg} / \text { day })\end{array}$ & $41.62 \pm 0.49 \mathrm{a}$ & $36.97 \pm 0.39 \mathrm{~b}$ & $29.66 \pm 0.35 \mathrm{c}$ \\
\hline Fat \% & $4.23 \pm 0.04 \mathrm{a}$ & $4.28 \pm 0.04 \mathrm{a}$ & $4.56 \pm 0.04 \mathrm{~b}$ \\
\hline Protein \% & $3.01 \pm 0.02 \mathrm{a}$ & $3.29 \pm 0.02 \mathrm{~b}$ & $3.51 \pm 0.02 \mathrm{c}$ \\
\hline Lactose \% & $4.80 \pm 0.01 \mathrm{a}$ & $4.76 \pm 0.01 \mathrm{~b}$ & $4.68 \pm 0.01 \mathrm{c}$ \\
\hline $\begin{array}{l}\text { Urea } \\
\mathrm{mg} / \mathrm{dl}\end{array}$ & $18.72 \pm 0.35 \mathrm{a}$ & $21.01 \pm 0.37 \mathrm{~b}$ & $22.14 \pm 0.30 \mathrm{c}$ \\
\hline $\begin{array}{l}\text { SCC x } 10^{3} \\
\text { cells/ml }\end{array}$ & $82.49 \pm 10.42 \mathrm{a}$ & $107.55 \pm 16.08 \mathrm{a}$ & $108.86 \pm 6.98 \mathrm{a}$ \\
\hline
\end{tabular}

\subsection{Cell number classes in the examined farm during investigation period:}

The following figure (4) give us information about the percentage of cell number classes in the examined milk samples. $79 \%$ of the milk samples have less than $100 \times 10^{3}$ cells $/ \mathrm{ml} \mathrm{milk.} \mathrm{Only} 11 \%$ of the total milk samples have more than $200 \times 10^{3} \mathrm{SCC}$ cells $/ \mathrm{ml}$ milk in the examined farm.

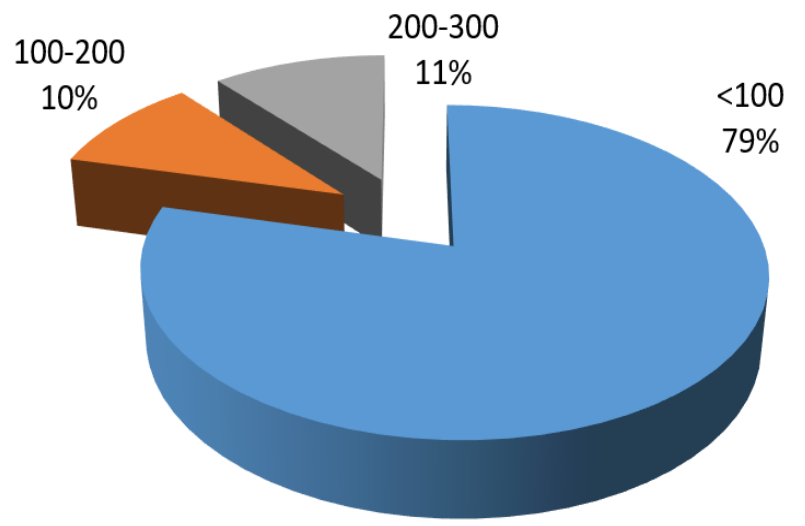

Fig. 4: Cell number classes $x 10^{3} /$ cells $/ \mathrm{ml}$ milk from the examined farm during investigation period

\subsection{Herd structure in the examined farm during investigation period:}

The Figure (5) provided information about the herd structure of the investigation farm in the study year. The herd structure was typical in the investigation farm, which has optimal management. As shown in the figure that $22 \%$ of dairy cows were in the first lactation. However, it should be noted that half of the dairy cows were in the third to fifth lactation.

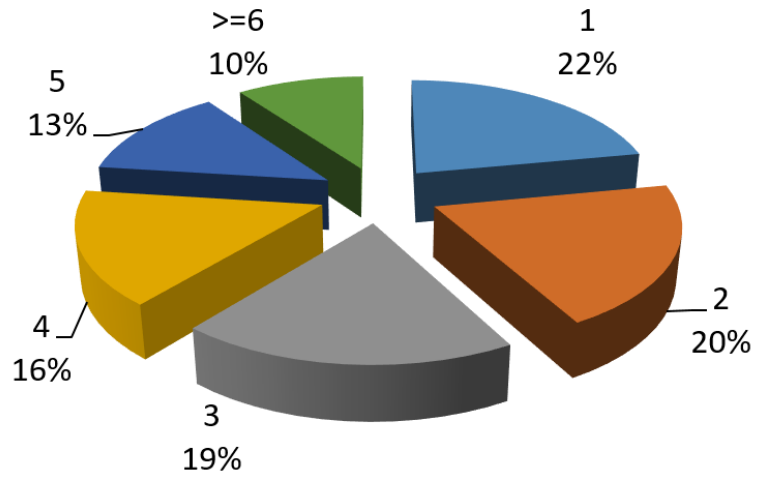

Fig. 5: Herd structure in the examined farm according to lactation number.

\subsection{Influence of the number of lactation on the examined milk parameters}

The daily milk yield increased to $43.59 \pm 0.97 \mathrm{~kg} /$ day by the fourth lactation. After that, it decreased slightly until the sixth and more lactations (Fig.3). This change of daily milk yield in term of lactation number is typical of the Holstein Friesian breed and it achieved via the optimal management in the farm. Fat and protein content are negatively correlated with the daily milk yield based on the number of lactation and the values were $(-0.36, \mathrm{P}<0.001)$ and $(-0.57, \mathrm{P}<0.001)$ respectively. Regarding the lactose content of the milk, the values were normal and ranged between 4.49 and $4.85 \%$. The milk urea content remained almost stable during lactations and the values varied between 19 and $21 \mathrm{mg} / \mathrm{dl}$ with no significant differences $(\mathrm{P}>0.05)$, since the feeding situation was optimal in the farm. SCC remained also lower than $100 \times 10^{3}$ cells $/ \mathrm{ml}$ until the third lactation. Then, SCC in milk increased from the fourth to sixth lactation slightly but the values remained below $215 \times 10^{3}$ cells $/ \mathrm{ml}$. 


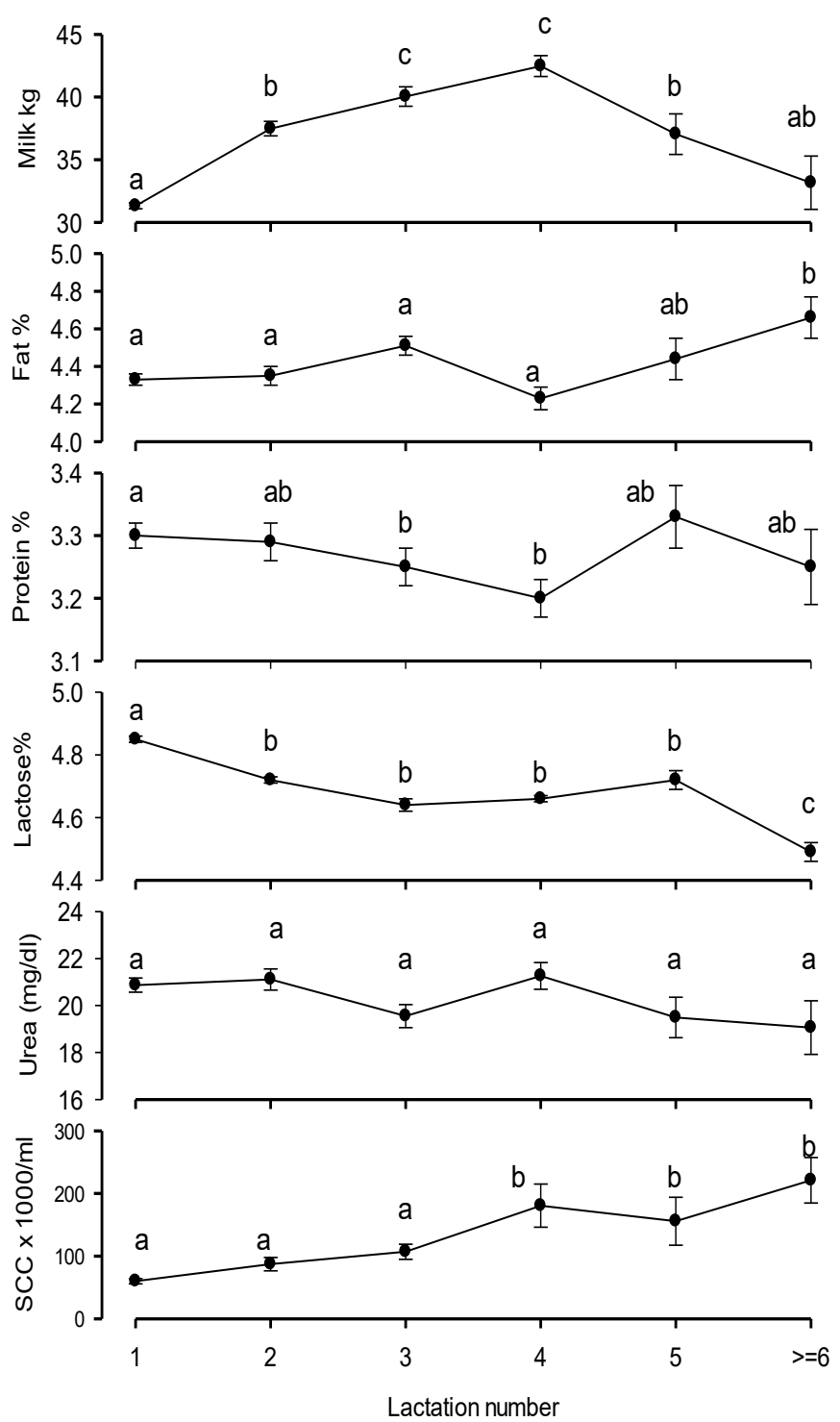

Fig. 3: Average milk parameters of the examined farm according to lactation numbers

\section{DISCUSSION}

\subsection{Milk performance:}

The influence of the milking machine on the high milk performance and quality primarily depends on the type and function of the milking machine. Is it compatible with the mother's calf sucking mechanism or not? Observations on suckling calves clearly showed that a calf is able to obtain the total amount of milk from their dam (including that from the alveoli) $(9,14)$. It is known that the well-being of the animals is increased by an optimal milking parlor and milking parlor design. Therefore, milking technology should ensure gentle, quick and complete extracted milk. The prerequisite for this is that the cows are able to milk.
This can be improved by intensive udder preparation and an optimally set milking technique. The results of the present study showed that the milking process ran well with ML milking system. Various studies have shown similar results and the daily milk yield increased by application of quarter individual milking system ML and the milk composition improved (8-10).

It is known that many factors affect milk performance and milk composition (15-19), but the milking system and milking routine play a crucial role $(6,7)$. However, milking routine and hygiene during the course of milk removal in this study have to be ideal. It is possible to have a suitable milking technique in the farm and at the same time the lactating cows are poorly milked. Kanswohl et al., (20) reported that milk removal is optimal during the milking time, when the used milking machine is suitable for the requirement of the lactating cows and the cows are well prepared before attaching the teat cups.

Moreover, usually the lactating cows reach their high milk yield shortly after calving (4-6 weeks) and then the daily milk yield steadily declines. Our results clearly showed that the daily milk yield remained quite high until the end of lactation session. That means that the cows have had the ability to continue their milk production at a high level after reaching the peak yield. Several reports indicated that the persistence with optimal management was over $85 \%$ in the second stage of lactation (21). Through breeding measures attempted to counteract this decline by selecting for the highest possible persistence of the performance, but no success has been shown (22-24). In this study, an explanation for maintaining the high milk yield until the end of lactation is associated with good husbandry, especially in the milking process and good feeding. As we know, milk is being produced during lactation session, the speed of production depends upon how empty the udder is. At this point, the frequency (three times) and completeness of emptying the udder during milking with ML have shown these results. Milking three times or more per day in relation to once or two times has been shown to increase milk yield by 6 to $50 \%(18,25-28)$.

On the other hand, an important requirement for milking technology in dairy cows is to complete extracting milk from the udder, since the remaining milk after milking inhibits the new milk synthesis (29). That means that there is a switch to the autocrine (or local) control system. In the course of lactation, milk removal is the primary control mechanism for milk production. It is therefore important to completely empty the udder as much as possible during milking. Bruckmaier, (22) reported that the frequency and completeness of emptying the udder 
during milking determine the activity of the existing lactocytes (epithelial cells in the alveoli), which is responsible for the increase in performance through increased milk synthesis and secretion and a slowed decline in performance over the course of lactation (persistence) is possible due to reduced apoptosis of the lactocytes. However, Alex et al., (18) found that changes in milk production in response to extreme differences in milking frequency may be related to alterations in mitochondrial number and lactose synthesis, but not apoptosis. In addition, many scientists have dealt with the dynamics of udder emptying during milking (30-37).

Furthermore, many studies have shown that udder preparation before attaching the teat cups has a positive effect on the course of milk removal (38-40). That means, it is important to prepare the animals optimally before milking. In this study excellent stimulation system with ML was used, as mentioned in the material and method. Therefore the udder has been completely emptied. Many scientists emphasize that the sufficient stimulation of the teats before milking is the cornerstone for the release of the hormone oxytocin and for a high milk flow and complete milking of the cows $(5,9,39,40)$.

\subsection{Milk composition:}

Milk composition can be affected by genetic and nongenetic factors for example, breed, stage of lactation, lactation number, milking process, husbandry, feeding, welfare and management $(39,41-44)$. In our study, only Holstein Friesian dairy cows were kept on the farm which normally produce low milk ingredients. But, our results show completely different results because the keeping conditions, especially the milking process with ML, have been very suitable for the cows. This was proven in the fact that the cows came voluntary to the milking parlor during the milking time.

Usually, the amount of obtained milk has a significant influence on the fat and protein contents in milk. That means, as the amount of milk increases, the fat and Protein content of the milk deceases because the amount of fat and protein in milk per day are limited and the percentage in one liter of milk are diluted due to a lot of milk (45). It is also interesting that the lowest levels of fat and protein in milk were shown in the fourth lactation session (Fig. 4). These change in the fat and protein content in milk by the stage or number of lactation were normal. However, the most important influence on the milk protein content is the energy supply and usable crude protein. It must also be noted that the ration and management control in the examined farm was optimal, since no significant mistakes were made in feeding or milking. Piccioli-Cappelli et al., (46) reported that the feed ration (amount and composition) must be changed in the course of lactation since endocrine-metabolic interactions can influence diet parameters, and so nutrient availability for the mammary gland can significantly vary and affect milk yield and its composition.

Furthermore, the obtained results clearly showed that the urea content of milk fluctuated between 19 and 21 $\mathrm{mg} / \mathrm{dl}$ in the course of lactation. Several reports have shown that the milk urea content may serve as an on-farm indicator to guide nutritional strategies (47-51). However, the limit values of urea for a normal raw protein supply vary between 15 to $20 \mathrm{mg}$ urea/dl milk. Milking intervals also affects the urea concentration in the obtained milk. That means, dairy cows which are milked three times a day, usually have higher urea in milk than those milked two times a day $(52,53)$. This statement explains that the urea concentrations in the milk were in the upper limit in our studies. It is noteworthy that the urea concentration in milk has increased continuously with the progress of lactation season (Tab.3). It was lowest during the first 100 $\mathrm{d}$ of lactation with $(18.72 \pm 0.35 \mathrm{mg} / \mathrm{dl})$, higher between 100 and $200 \mathrm{~d}$ in milk with $(21.01 \pm 0.37 \mathrm{mg} / \mathrm{dl})$ and the highest after $200 \mathrm{~d}$ in milk with $(22.14 \pm 0.30 \mathrm{mg} / \mathrm{dl})$. Similar results have been shown by Godden et. al., (54). Furthermore, it should be noted that lactation number in this study has no significant influence on the urea concentration in milk similar to those reportedly HenaoVelasquez et al., (55).

It is known that many factors affect SCC in milk. Although the lactating cows produced high milk yield, the SCC in milk was low during the study period, as shown in Table (2). These results differ from the prevailing opinion that with high milk production the animals are more stressed and the result is an increased SCC in the produced milk (56). As shown in Table (3), the stage of lactation had no significant $(\mathrm{P}>0.05)$ effect on the $\mathrm{SCC}$ in obtained milk. But the lowest level of SCC was in the first stage of lactation and then increased slowly throughout the second and third stages of lactation. These results were also in agreement with Kennedy et al., (57) and Sheldrake et al., (58). The significant influence of parity on SCC in milk was clearly shown in Figure (2). That is, the SCC remained below $100 \times 10^{3}$ cells $/ \mathrm{ml}$ without significant differences $(\mathrm{P}>0.05)$ up to third lactation; however, it increased significantly $(\mathrm{P}<0.05)$ in cows having more than four parity. This corresponds to the results of some researchers (59-61). 
On the other hand, SCC and milk quality depend mainly on milking technology and milking routine (6). However, the milk of healthy udders contains less than 100 $\mathrm{x} 10^{3}$ cells $/ \mathrm{ml}$. With the irritation and inflammation of the udder quarters, the SCC can rise sharply and up to 20-50 million cells $/ \mathrm{ml}$ can be achieved. Therefore, the pathogen detection must be carried out in the udder quarter if the cell count in the milk is determined to be more than $100 \times 10^{3}$ cells $/ \mathrm{ml}$.

Stress during milking is one of the significant factors, which has a negative effect on the SCC in the milk as found in automatic milking systems compared to conventional milking parlors (62). Similarly, Castro et al., (63) found that the SCC values were significantly higher during the 12-month post-installation of the automatic milking system. During the milking course, timing of oxytocin release and milk ejection before the start of milk removal is very important for subsequent milking performance (64) and any interruption of the milk ejection process can disturb milk removal. The result is inflammation in the udder (7). The indicator of inflammation in the udder is an increase in SCC in the removed milk (5). Therefore, ergonomic milking system and responsible milkers are very important for the welfare of dairy cows (65). During the use of the ML milking system in this study, it became clear that there was no stress during milking, as it had a special stimulation system before and during milking that played a crucial role in improving SCC in milk. Therefore, the SCC remained below $100 \times 10^{3}$ cells $/ \mathrm{ml}$ during the investigation period. Previous study reported that the ML milking system showed significantly better results in terms of teat color after milking compared to the conventional milking system (66). It is noteworthy that the remaining rest milk in the udder after milking not only adversely affects milk performance, but also affects udder health. Our results clearly showed that the ML milking system had completely emptied the udder, since the obtained milk was high and the SCC remained low. Moreover, Alhussien and Dank (67) emphasized that milk with low SCC means better milk products with a longer shelf life.

\subsection{Lactation number and useful life:}

Increasing milk yield should not only be achieved through genetic progress $(43,68)$, but should also be increased through the life performance of dairy cows. Therefore, an increase in life efficiency is possible by lowering the first calving age (69), increasing the milk yield per lactation and extending the useful life at a high performance level.
Our obtained results demonstrated that the udder remained healthy during milking and the cows remained longer in the farm as shown in the figure (5). The average lactation season in the trial year was 3.31 in the farm. Currently, there is an average useful life of approximately 2.5 lactations in Germany (70). However, the highest performance of the lactating cows could be achieved in the 4 th or 5 th lactation $(15,71)$. Previous studies have reported that the dairy farms with the ML milking systems have clearly shown that the useful life of the dairy cows is extended because the cows live longer and their performance potential is fully exhausted (10). So that in terms of cow's milk yield, a long useful life with a good performance effect the utilization of the age related performance maximum. As the efficiency of feed conversion increases and the rearing costs per $\mathrm{kg}$ milk decrease over a longer useful life.

\section{CONCLUSION}

A complete milking routine with milking machine can achieve good results by completely emptying the udder and significantly reducing the risk of blind milking. That is why by using new technology MultiLactor, a high milk yield and a better milk quality can be achieved, since it is adapted to the physiology of the dairy cows. The following observation were also observed during the milking with MultiLactor:

- The cows came voluntarily to the milking parlor.

- The cows were quiet during milking.

- The teat cups were never knocked off.

- Very small residual milk remained in the udder after milking.

Beyond, it was observed that ML milking system has positive influenced on SCC content in milk and the udders remained healthy during the investigation period.

\section{REFERENCES}

[1] Jungbluth, T., Büscher, W. \& Krause, M. (2005). TechnikTierhaltung. 1. Aufl. Stuttgart: UTB Ulmer.

[2] Becker, N. (2016). Entwicklung der Milchleistungsparameter bei Milchkühen unterschiedlicher Milchviehbetriebe nach der Umstellung auf das viertelindividuelle Melksystem MultiLactor. Master, Technische Universität München, Agrarsystemtechnik.

[3] Ströbel, U., Rose-Meierhöfer, S., Öz, H., Entorf, A.-C., Popp, L. \& Brunsch, R. (2011). Analysis and evaluation of the teat-end vacuum condition in different automatic milking 
systems. Irish Journal of Agricultural and Food Research 50(2): 209-221.

[4] Jungbluth, T. \& Grimm, H. (2009). Melken und Melktechnik- zukünftiger Forschungsbedarf. 2.Tänikoner Melktechniktagung, 25-26 März 2009, Forschungsanstalt Agroscope Tänikon, Ettenhausen, Switzerland.

[5] Bruckmaier, R.M. (2001). Milk ejection during machine milking in dairy cows. Livestock Production Science 70: 121-124.

[6] Dang, A. K. \& Anand, S. K. (2007). Effect of milking systems on the milk somatic cell counts and composition. Livest. Res. Rural Dev. 19(6): 1-8.

[7] Petrovska, S. \& Jonkus, D. (2014). Milking Technology Influence on Dairy Cow Milk Productivity and Quality. 13th International Scientific Conference, Engineering for Rural Development. Proceedings 13 May 29-30, 2014 Jelgava, Latvia, Ukraine.

[8] Kaskous, S. \& Fadlelmoula, A. (2015). Adaptability of dairy cows to individual quarter milking system after changing from tying to loose housing system. Advances in Animal and Veterinary Sciences 3(4): 225-232.

[9] Kaskous, S. (2016). Alte Kühe dank neuer Melktechnik. Hessens Zukunft. 16(3): 36-39.

[10] Kaskous, S. (2018a). The effect of using quarter individual milking system "MultiLactor" on improvement of milk performance and milk quality of different dairy cows breeds in different farms. Emirate Journal of Food and Agriculture 30(1): 57-64.

[11] Kaskous, S. (2018b). Optimization of the pulsation ratio during the course of milk removal after using a quarter individual milking system "MultiLactor". International Journal of Agriculture Innovations and Research 6 (6): 284289.

[12] Müller, A.B., Rose-Meierhöfer, S., Ammon, C. \& Brunsch, R. (2011). Comparison of the effects of quarter-individual and conventional milking system on milk ability traits. Archiv Tierzucht 54(4): 360-373 .

[13] SAS Institute, Version 8, Cary NC, USA, 1998.

[14] Kälber, T. \& Barth, K. (2014). Practical implications of suckling systems for dairy calves in organic production systems-a Review. Appl. Agric Forestry Res. 64:45-58.

[15] Fahr, R. D. \& Lengerken, G. (2003). Milcherzeugung, Grundlage Prozesse- Qualitätssicherung. Deutscher Fachverlag. Germany.

[16] Dufour, S., Frechette A., Barkema, H. W., Mussell, A. \& Scholl, D. T. (2011). Invited review: Effect of udder health management practices on herd somatic cell count. J. Dairy Science 94: 563-579.

[17] Assan, N. (2014). Significance of litter size, duration of dry period and stage of pregnancy on milk yield and composition in dairy animals. Science Journal of Rev. 3(12): 993-1003.

[18] Alex, A.P., Collier, J. L., Hadsell, D. L. \& Collier, R. J. (2015). Milk yield differences between $1 x$ and $4 x$ milking are associated with changes in mammary mitochondrial number and milk protein gene expression, but not mammary cell apoptosis or SOCS gene expression. Journal of Dairy Science 98(7): 4439-4448.

[19] Cinar, M., Serbester, U., Ceyhan, A. \& Gorgulu, M. (2015). Effect of somatic cell count on milk yield and composition of first and second lactation Dairy cows. Ital. J. Anim. Sci. 14(1): 105-108.

[20] Kanswohl, N., Schlegel, M., Burgstaler, J. \& Wiedow D. (2012). Zügig ans schonend melken. Bauernblatt. 40: 39-41.

[21] Römer, A. (2012). Managementhilfen im MilchviehstallMöglichkeiten und Grenzen. 1. Auflage Bayerische Landesanstalt für Landwirtschaft, Germany: 21-48.

[22] Bruckmaier, R. M. (2007). Physiology of lactation In: Kroemker V. Milk science and milk Hygiene. Parey. 2007:6-21.

[23] Mandokhial, K.-U., Kaleri, H. A., Kaleri, R. R., Kaleri, A., Safi, A. S., Kaleri, A.H. \& Safi M. A. (2017). Study on persistency of lactation in Holstein Friesian cattle. Pure and Applied Biology 6 (1): 159-163.

[24] Koloi, S., Pathak, K., Behera, R., Mandal, D. K., Karunakaran, M., Dutta, T. K. \& Mandal, A. (2018). Factors affecting the persistency of milk production in Jersey crossbred cattle. Journal Dairy, Veterinary and Animal Research 7(6): 268-271.

[25] Klei, L. R., Lynch, J. M., Barbano, D. M., Oltenacu, P. A., Lednor, A. J. \& Bandler, D. K. (1997). Influence of milking three times a day on milk quality. Journal dairy Science 80: 427-436.

[26] Collier, R. J., Romagnolo, D. \& Baumgrad, L. H. (2010). Lactation (f) galactopoiesis/seasonal effects. In: Roginski H., Fuquay J.W. and Fox P.F. Encyclopedia of Dairy Science. Ed Academic Press, New York, NY: 35-46.

[27] Atashi, H. (2015). Effect of milking frequency on the lactation performance and lactation curve of Holstein dairy cows in Iran. Iranian Journal of Applied Animal Science 5(2): 273- 278 .

[28] Boujename, I. (2019). Effect of milking frequency on milk production and composition of Holstein cows during their first three lactations. Iranian Journal of Applied Animal Science 9(1): 25-29.

[29] Wilde, C. J. \& Peaker, M. (1990). Autocrine control in milk secretion. J. Agric. Sci. 114: 235-238.

[30] Capuco, A. V., Wood, D. L., Baldwin, R., Mcleod, K. \& Paape, M. J. (2001). Mammary cell number, proliferation, and apoptosis during a bovine lactation: relation to milk production and effect of bST. Journal of Dairy Science 84: 2177-2187. 
[31] Nørgaard, J., Sørensen, A., Sørensen, M. T., Andersen, J. B. \& Sejrsen, K. (2005). Mammary cell turnover and enzyme activity in dairy cows: Effects of milking frequency and diet energy density. J. Dairy Science 88: 975-982.

[32] Fitzgerald, A. C., Annen-Dawson, E. L., Baumgard, L. H. \& Collier, R. J. (2007). Evaluation of continuous lactation and increased milking frequency on milk production and mammary cell turnover in primiparous Holstein cows. Journal of Dairy Science 90: 5483-5489.

[33] Hickson, R. E., Lopez-Villalobos, N., Dalley, D. E., Clark, D. A. \& Holmes, C. W. (2006). Yields and persistency of lactation in Friesian and Jersey cows milked once daily. Journal of Dairy Science 89, 2017-2024.

[34] Caja, G., Ayadi, M. \& Knight, C. H. (2004). Changes in cisternal compartment based onstage of lactation and time since milk ejection in the udder of dairy cows. Journal of Dairy Science 87: 2409-2415.

[35] Berry, D. P., Coughlan, B., Enright, B., Coughlan, S. \& Burke, M. (2013). Factors associated with milking characteristics in dairy cows. Journal of Dairy Science 96: 5943-5953.

[36] Penry, J. F., Endres, E. L., DE Bruijn, B., Kleinhans, A., Crump, P. M., Reinemann, D. J. \& Hernandez, L.L. (2017). Effect of incomplete milking on milk production rate and composition with 2 daily milkings. Journal of Dairy Science 100 (2): 1535-1540.

[37] Gasqui, P. \& Trommenschlager, J.-M. (2017). A new standard model for milk yield in dairy cows based on udder physiology at the milking-session level. Scientific Reports 7(1): 1-11.

[38] Weiss, D. \& Bruckmaier, R.M. (2005). Optimization of individual pre-stimulation in dairy cows. J. Dairy Science. 88: 137-147.

[39] Tancin, V., Uhrincat, M., Macuhova, J. \& Bruckmaier, R. M. (2007). Effect of pre- stimulation on milk flow pattern and distribution of milk constituents at a quarter level. Czech J. Anim. Sci. 52(5): 117-121.

[40] Kaskous, S. \& Bruckmaier, R. M. (2011). Best combination of pre-stimulation and latency period duration before cluster attachment for efficient oxytocin release and milk ejection in cows with low to high udder-filling levels. Journal of Dairy Research 78:97-104

[41] Auldist, M.J., Coats, S., Rogers, G. L. \& McDowell, G. H. (1995). Changes in the composition of milk from healthy and mastitic dairy cows during the lactation cycle. Australian Journal of Experimental Agriculture 35(4): 427 436

[42] Hagen, K., Langbein, J., Schmied, C., Lexer, D. \& Waiblinger, S. (2005). Heart rate variability in dairy cowsinfluences of breed and milking system. Physiology and Behavior 85 (2): 195-204.
[43] Oltenacu, P. A. \& Broom, D. M. (2010). The impact of genetic selection for increased milk yield on the welfare of dairy cows. Animal Welfare 19(1): 39-49.

[44] Mullen, M.P., Lynch, C. O., Waters, S. M. (2011). Single nucleotide polymorphisms in the growth hormone and insulin-like growth factor-1 genes are associated with milk production, body condition score and fertility traits in dairy cows. Genetics and Molecular Research 10: 1819-1830.

[45] Richardt, W. (2004). Milchinhaltsstoffe als Indikatoren für Fütterung und Gesundheit von Milchkühen. Fachtagung 2003/2004, Deutsche Vilomix Tierernährung; Sächsischer Landeskontrollverband e.V., Lichtenwalde.

[46] Piccioli-Cappelli, F., Loor, J. J., Seal, C. J., Minuti, A. \& Trevisi, E. (2014). Effect of dietary starch level and high rumen-undegradable protein on endocrine-metabolic status, milk yield, and milk composition in dairy cows during early and late lactation. Journal Dairy Science 97(12): 7788-7803.

[47] Eicher, R., Bouchard, E. \& Bigras-Poulin, M. (1999). Factors affecting milk urea nitrogen and protein concentration in Quebec dairy cows. Preventive Veterinary Medicine 39(1): 53- 63.

[48] Olmos Colmenero, J. J. O. \& Broderick, G. A. (2006). Effect of dietary crude protein concentration on milk production and nitrogen utilization in lactating dairy cows. Journal of Dairy Science 89 (5):1704-1712.

[49] Borucki Castro, S. I., Phillip, L. E., Lapierre, H., Jardon, P. W. \& Berthiaume, R. (2008). The relative merit of ruminal undegradable protein from soybean meal or soluble fiber from beet pulp to improve nitrogen utilization in dairy cows. Journal of Dairy Science 91: 3947-3957.

[50] Spek, J. W., Dijkstra, J., Van Duinkerken, G. \& Bannink A. (2013). A review of factors influencing milk urea concentration and its relationship with urinary urea excretion in lactating dairy cattle. Journal of Agricultural Science 151: 407-423.

[51] Siachos, N., Panousis, N., Arsenos, N. \& Valergakis, G. (2017). Investigation of milk urea nitrogen concentration and factors affecting its variation in Greek Holstein herds. Journal of the Hellenic Veterinary Medical Society 68(3): 423-432.

[52] Nielsen, N.L., Larsen, T., Bjerring, M. \& Ingvartsen, K.L. (2005). Quarter health, milking interval, and sampling time during milking affect the concentration of milk constituents. Journal of Dairy Science 88:3186-3200.

[53] Friggens, N.C. \& Rasmussen, M. D. (2001). Milk quality assessment in automatic milking systems: accounting for the effects of variable intervals between milking's on milk composition. Livestock Production Science 73: 45-54.

[54] Godden, S. M., Lissemore, K.D., Kelton, D. F., Leslie, K. E., Walton, J. S. \& Lumsden, J. H. (2001). Factors associated with milk urea concentrations in Ontario dairy cows. Journal Dairy Science 84(1): 107-114. 
[55] Henao-Velasquez, A. F., Munera-Bedoya, O. D., Herrera, A. C., Agudelo-Trujillo, J. H. \& Ceron-Munoz, M. F. (2014). Lactose and milk urea nitrogen: fluctuations during lactation in Holstein cows. Revista Brasileira de Zootecnia 43(9): 479-484.

[56] Mukherjee, J. and Dank, A. K. (2011). Immune activity of milk leukocytes during early lactation period in high and low yielding crossbred cows. Milchwissenschaft 66: 384388.

[57] Kennedy, B. W., Sethar, M. S., Tong, A. K.W., Moxley, J. E. \& Downey, B. R. (1982). Environmental factors influencing test-day somatic cell counts in Holsteins. Journal dairy Science 65: 275-280.

[58] Sheldrake, R. F., Hoare, R. J. T. \& McGregor, G. D. (1983). Lactation stage, parity, and infection affecting somatic cells, electrical conductivity, and serum albumin in milk. Journal Dairy science 66: 542-547.

[59] Geneurova, V., Hanns, O., Gabriel, B. \& Zvackova, I. (1993). Somatic cell counts of milk in relation to production factors. Zivocisna Vyroba 38: 359-367.

[60] Saravanan, R., Das, D. N., De, S. \& Panneerselvam, S. (2015). Effect of season and parity on somatic cell count across zebu and crossbred cattle population. Indian Journal Animal Research 49: 383-387.

[61] Goncalves, J. L., Cue, R. L., Botaro, B. G., Horst, J. A., Valloto, A. A. \& Santos, M. V. (2018). Milk losses associated with somatic cell counts by parity and stage of lactation. Journal Dairy Science 101 (5): 4357-4366.

[62] Gygas, L., Neuffer, I., Kaufmann, C., Hauser, R. \& Wechsler, B. (2008). Restlessness behavior, heart rate and heart-rate variability of dairy cows milked in two types of automatic milking systems and auto-tandem milking parlours. Applied Animal Behavior Science 109 (2): 167179.

[63] Castro, A., Pereira, J. M., Amiama, C. \& Bueno, J. (2015). Typologies of dairy farms with automatic milking system in northwest Spain and farmer's satisfaction. Italian Journal of Animal Science 14 (2): 207-219.

[64] Bruckmaier, R. M., Macuhova, J. \& Meyer, H. H. D. (2001). Specific aspects of milk ejection in robotic milking: A review. Livestock Production Science 72: 169-176.

[65] Rushen, J., Munksgaard, L., Marnet, P. G., \& De Passille, A. M. (2001). Human contact and the effects to acute stress on cows at milking. Applied Animal Behavior Science 73 (1): 1-14.

[66] Rose-Meierhöfer, S., Müller A. B., Mittmann, L., Demba, S., Entorf, A. C. H., Hoffmann, G., Ammon, C., Rudovesky, H. J. \& Brunsch, R. (2014). Effects of quarter individual and conventional milking systems on teat condition. Prev. Vet. Med. 113: 556-564.

[67] Alhussien, M. N. \& Dang, A. K. (2018). Milk somatic cells, factors influencing their release, future prospects, and practical utility in dairy animals: An overview. Veterinary World.11 (5): 562-577.

[68] Stranden, I., Kantanen, J., Russo, I.-R. M., Wengel, P. O-T., Bruford, M. W. \& Consortium, C. (2019). Genomic selection strategies for breeding adaptation and production in dairy cattle under climate change. Heredity 123: 307-317.

[69] Freuen, S. \& Hoy, S. (2020). So wirkt sich das Erstkalbealter auf die Lebensleistung aus. Milchpraxis 54(2): 12-14.

[70] Hanauska, A. (2019). Analyse der Entwicklung der Milchleistung in den ersten fünf Laktationen bei Kühen der Rasse Deutsche Holstein unter Beachtung ausgewählter Einflussfaktoren in einem Betrieb in Baden-Württemberg. Bachelorarbeit 72 Seiten, Fachbereich Landwirtschaft, Hochschule Anhalt Bernburg

[71] Mellado, M., Antonio-Chirino, E., Meza-Herrera, C., Veliz, F. G., Arevalo, J. R., Mellado, J. \& De Santiago, A. (2011). Effect of lactation number, year, and season of initiation of lactation and treated with recombinant bovine somatotropin. J. Dairy Sci. 94 (9): 4524- 4530. 